\title{
Preservation of seagrass clonal integration buffers against burial stress
}

\author{
F. Tuya ${ }^{a^{*}}$, F. Espino ${ }^{a}$, J. Terrados ${ }^{b}$ \\ a Centro en Biodiversidad y Gestión Ambiental, Marine Sciences Faculty, Universidad \\ de Las Palmas de Gran Canaria, Las Palmas, Canary Islands, Spain \\ ${ }^{b}$ Instituto Mediterráneo de Estudios Avanzados, IMEDEA (CSIC-UIB), C/ Miquel \\ Marquès, 21 - 07190 Esporles, Islas Baleares, Spain
}

*Corresponding author at: Centro en Biodiversidad y Gestión Ambiental, Marine Sciences Faculty, Universidad de Las Palmas de Gran Canaria, Las Palmas, Canary Islands, Spain. Tel: +34 928452900; fax: +34 928452900 .

E-mail adress: ftuya@yahoo.es 
ABSTRACT. The survivorship and performance of seagrasses are affected by environmental stressors, yet clonal integration of seagrasses can ameliorate these adverse environmental changes. We experimentally assessed the response of the seagrass Cymodocea nodosa (Ucria) Ascherson off Gran Canaria to changes in the intensity of burial, determining whether responses could be modulated by the clonal integration of the plant. Plants were buried in situ to 0 ('ambient'), 8 ('moderate') and $24 \mathrm{~cm}$ ('high') within PVC cylinders, which were left untouched or isolated from adjacent shoots by sawing their clonal connection. The number of living shoots under 'moderate' and 'high' burial scenarios declined with time when the clonal integration was severed. After 15 weeks, cores were harvested. The effect of burial over of $C$. nodosa depended on whether the clonal integration was maintained or severed. When the clonal integration was maintained, the shoot density, the number of leaves, the above-ground biomass and the leaf length did not change significantly with burial levels. When the clonal integration was severed, the shoot density and the number of leaves were larger in cores under 'ambient' and 'moderate' than 'high' burial levels, the above-ground biomass was larger under 'ambient' than 'moderate' and 'high' burial levels, and the leaf length was larger in 'ambient' than in cores under 'high' burial. The below-ground biomass was not affected by burial and clonal integration. The internodal length of vertical rhizomes increased with burial; this increase was larger when the clonal integration was severed. In conclusion, preservation of the clonal integration of the seagrass C. nodosa buffered seagrass performance against small-scale burial events.

Keywords: seagrass, Cymodocea nodosa, disturbance, sedimentation, clonality, Canary Islands 


\section{Introduction}

Seagrass meadows are one of the most productive marine habitats, providing high-value ecosystem good and services, which has caused their inclusion within different international conservation legislative frameworks, e.g. EU 92/43/CEE Habitats Directive (Hemminga and Duarte, 2000). Conservation of these habitats is therefore important, since seagrass meadows are declining worldwide, particularly in areas of intense human-mediated disturbances, such as large urban and industrial coastal zones (Hughes et al., 2009; Waycott et al., 2009).

Seagrasses typically occur on shallow-water soft substrates where they are naturally subjected to physical mechanisms that redistribute sediments, causing events of burial and erosion over seagrasses (Marbá et al., 1994; Cabaço and Santos 2007). In addition, coastal run-off, construction of infrastructures (e.g. ports, marinas, dikes) and associated activities, particularly dredging, may cause a redistribution of sediments and so abrupt sedimentation (burial) events (Ruiz and Romero, 2003; Cabaço and Santos, 2007). These episodes can partially, or totally, bury seagrasses (reviewed by Cabaço et al., 2008). Seagrasses experience then physiological and morphological responses, mainly as a result of a decrease in the amount of actively photosynthetic parts of seagrass shoots and an elevation of the sediment anoxic level towards the photosynthetic parts of seagrass shoots. In particular, the growth of vertical rhizomes is enhanced under burial to promote photosynthetic compartments to reach light and subsequently stimulate seagrass survivorship and performance (e.g. Marbá and Duarte, 1994; Terrados, 1997; Manzanera et al., 2011). Seagrass responses, however, can vary among species (Duarte et al., 1997; Terrados et al., 1998; Cabaço et al., 2008; Sim Ooi et al., 2011). Seagrasses are clonal plants and, therefore, nutrients and resources are translocated between adjacent shoots to cope with adverse environmental conditions; a relevant factor that 
can facilitate seagrass performance and survivorship during periods of high stress (Tomasko and Dawes, 1989; Terrados et al., 1997a; Marbá et al., 2002), including short-term burial events (Sim Ooi et al., 2011).

Small-scale in situ manipulations of burial have been performed on a suite of seagrasses, according to different burial levels and durations (reviewed by Cabaço et al., 2008). These studies have provided a wealth of knowledge to assess those limits of sediment burial that can be tolerated by different seagrasses to avoid an irreversible deterioration. Except for a recent study (Sim Ooi et al., 2011), these studies have, however, maintained the clonal (connection) integration of shoots under experimentation with adjacent shoots. This could potentially ameliorate the negative effects of burial on seagrass performance, as a result of the transfer of nutrients and resources from neighbouring, undisturbed, shoots (Tomasko and Dawes, 1989; Sim Ooi et al., 2011).

The marine phanerogam Cymodocea nodosa (Ucria) Ascherson is distributed across the Mediterranean Sea and the adjacent eastern Atlantic, including the arquipelagos of Madeira and the Canaries. Meadows constituted by $C$. nodosa are the dominant vegetated communities on shallow soft substrates across the Canaries (Barberá et al., 2006), providing food and shelter for diverse invertebrate and fish assemblages (Tuya et al., 2001; Espino et al., 2011). These meadows are generally located along the eastern and southern coasts of the islands, forming extensive, but fragmented, subtidal meadows. Oceanic swells and large wind-driven seas cause severe movements of sediments that routinely alter the local cover and density of C. nodosa (Marbá et al. 1994), including seagrass meadows in the Canaries (Portillo, 2007). The horizontal rhizomes of $C$. nodosa do connect shoots a few meters apart, so resources can be translocated among neighbouring shoots; in fact, this plant has been considered as an 
appropriate candidate to study the effects of clonal integration on the physiology and ecology of seagrasses (Terrados et al., 1997b). When subjected to experimental burial, the survivorship of $C$. nodosa seedlings has declined with the level of experimental burial, though $C$. nodosa seedlings have tolerated a burial $<7 \mathrm{~cm}$ (Marbá and Duarte, 1994). Burial promoted the growth of $C$. nodosa seedlings under a moderate burial; in turn, C. nodosa seedling growth has showed a bell-shaped response to experimental burial (Marbá and Duarte, 1994). The response of C. nodosa adult shoots to in situ experimental burial, however, has not been tested.

In this study, we aimed to experimentally assess the response of the seagrass $C$. nodosa to changes in the intensity of burial, determining whether responses could be modulated by the clonal integration of the plant. We hypothesized that preservation of the seagrass clonal integration would ameliorate the stress induced by burial on seagrass vitality.

\section{Materials and methods}

\subsection{Experimental design}

This study was carried out on a $C$. nodosa meadow located at 8-9 m depth off the south coast of Gran Canaria (N $27^{\circ} 44.923^{\prime}$, W 15 33.855'). A previous study (Barberá et al., 2006) indicated that the mean height of $C$. nodosa leaves was ca. $32 \mathrm{~cm}$ off the south of Gran Canaria. Three burial treatments were then established, on the basis of this value, corresponding to $0 \mathrm{~cm}(0 \%$ of burial), $8 \mathrm{~cm}(25 \%)$ and $24 \mathrm{~cm}(75 \%)$ of the mean height, respectively, following a previous study that used a parallel approach (Mills and Fonseca, 2003). Thereafter, these treatments will be considered as: 'ambient', 'moderate' and 'high' burial, respectively. Treatments were established within $20 \mathrm{~cm}$ inner diameter PVC opaque cylinders; adjacent cylinders were, at least, $0.5 \mathrm{~m}$ apart. Two $50 \mathrm{~cm}$ metal stakes were attached to each cylinder on its outer side through cables 
ties, and hammered into the bottom to assure cylinders were not moved away by waves and currents. In all cases, cylinders were filled with sand from an adjacent sandy unvegetated patch. Twelve cylinders (i.e. 4 per treatment) were randomly allocated on each of two seagrass patches. On one patch, all plots were left untouched, while all plots on the second patch were isolated from adjacent shoots by halting their clonal connection, i.e. sawing horizontal rhizomes, around each plot down to $30 \mathrm{~cm}$ inside the seabed. Both patches were separated by ca. $100 \mathrm{~m}$, so no treatment (clonal integration) confounding was expected. The experiment was set up on the $5^{\text {th }}$ of May-2011, and revisited every 5 weeks to ensure burial levels were appropriately maintained. On each occasion, we also counted the number of living shoots in each cylinder. After 15 weeks, all 24 cylinders were harvested, including above and below-ground compartments. To provide a baseline to compare seagrass responses against, four replicate natural samples were also collected haphazardly from a seagrass patch about $100 \mathrm{~m}$ away from the experimental set up. All material was transferred to labelled bags and frozen $\left(-20^{\circ} \mathrm{C}\right)$ until processed in the lab.

\subsection{Seagrass responses}

For each sample (cylinder), we counted the number of living shoots and the total number of leaves. The length of 10 leaves without apparent necrosis and the length of the youngest vertical internode (for 5 shoots) was also measured. This internode has been shown to elongate during a similar experiment (Marbá and Duarte, 1994). The seagrass biomass was separated into above (leaves) and below-ground sections (horizontal rhizomes and roots) and subsequently oven-dried $\left(24 \mathrm{~h}\right.$ at $\left.70^{\circ} \mathrm{C}\right)$ to obtain dry-weight biomass measurements. 


\subsection{Statistical analyses}

Since the number of living shoots within cores was followed through time, a repeatedmeasures ANOVA (RM-ANOVA) tested whether shoot survivorship differed between burial (sedimentation) levels and the presence/absence of clonal integration through time. Permutation-based ANOVAs (Anderson, 2001) were used to test whether burial levels and the presence/absence of clonal integration affected seagrass responses; both factors were treated as fixed. Analyses were based on Euclidean distances and P-values calculated from 4999 unrestricted permutations of the raw data. Despite all data were $\ln (\mathrm{x}+1)$ transformed to stabilize heterogeneous variances, homogeneous variances were only obtained for the ANOVA performed on the below-ground biomass (Cochran test's; $\mathrm{P}>0.05)$. As a result, we reduced an increase in a type I error rate by taking a more conservative alpha at the 0.01 level (Underwood, 1997). Because in almost all cases we detected a significant interaction term between burial (sedimentation) treatments and the presence/absence of clonal integration, pairwise comparisons (using 4999 permutations) were used to resolve differences among burial levels separately when the clonal integration was maintained or severed.

\section{Results}

The number of living shoots through time was dependent on both sedimentation treatments and maintenance (or not) of the clonal integration of the seagrass (Fig. 1a and 1b; Table 1, R-M ANOVA: 'Times x Sed' and 'Times x CI', P<0.0001). The number of living shoots under 'moderate' and 'high' burial scenarios particularly declined with time when the clonal integration was severed (Fig. 1b; Table 1, R-M ANOVA: 'Sed $\mathrm{x}$ CI', $\mathrm{P}=0.002)$. At the end of the experiment, the effect of sedimentation treatments over C. nodosa depended, except for the below-ground 
biomass, on whether the clonal integration of the plant was maintained or severed (Fig.2; Table 2, ANOVAs: 'Sed x CI', P $<0.05$ for all responses, except the belowground biomass). When the clonal integration was preserved, the shoot density, the number of leaves, the above-ground biomass and the leaf length of C. nodosa did not significantly change among burial levels (Figs. 2A, 2B, 2C and 2F, respectively, pairwise tests), although a slight decrease in the number of leaves and the above-ground biomass under an 'high' burial scenario was observed (Figs. 2B and 2C). When the clonal integration was severed, however, the shoot density and the number of leaves was significantly larger in cores subjected to 'ambient' and 'moderate' than 'high' burial levels (Figs. 2A and 2B, respectively, pairwise tests), the above-ground biomass was significantly larger in cores under 'ambient' than 'moderate' and 'high' burial levels (Fig. 2C, pairwise tests), and the leaf length was larger in 'ambient' than cores under 'high' burial (Fig. 2F, pairwise tests). The below-ground biomass did not change with either sedimentation levels or preservation/destruction of the clonal integration (Fig. 2D; Table 2, ANOVA: all terms, P> 0.05). The internodal length of vertical rhizomes increased with sedimentation (Fig. 2E; Table 2, ANOVA: 'Sed', P=0.0008, pairwise tests indicated a larger internodal length under 'high' than 'moderate' and 'ambient' burial levels); the magnitude of this increase was larger when the clonal integration was severed (Fig. 2E; Table 2, ANOVA: 'Sed x CI', $\mathrm{P}=0.0001$ ).

\section{Discussion}

Our study has shown a decline in C. nodosa shoot survivorship through a 15 week experimental period when burial was accompanied by severing the seagrass clonal integration. The negative effect of burial on shoot survivorship through time of largesized seagrasses has been previously experimentally observed (e.g. Marbá and Duarte, 
1994; Mills and Fonseca, 2003; Manzanera et al., 2011). Our study did not examine the specific reasons underlying this decrease in shoot density with burial. Mortality of shoots may be driven by different mechanisms. First, reductions in the amount of surface that can capture solar light produce a decrease in the photosynthesis yield and oxygen levels in the meristems (Terrados, 1997). Second, decaying shoots increase organic matter pools that may decrease oxygen levels in the porewater and promote anoxic conditions. Sediment anoxia can seriously affect seagrass performance, inducing seagrass shoots mortality (Holmer et al., 2005; Holmer et al., 2009). Importantly, our study has demonstrated that the effect of burial on shoot survivorship and performance of $C$. nodosa clearly depended on whether the clonal integration of the plant was maintained or severed. Preservation of the clonal integration allowed C. nodosa to remain relatively unaltered under both 'moderate' and 'high' burial scenarios relative to 'ambient' levels during 15 weeks, although a slight decrease in the number of leaves and the biomass of above-ground compartments under an 'high' burial scenario was suggested. From a theorical perspective, this result reinforces the view of the relevant role that preservation of the clonal integration of seagrasses has on mitigating seagrass deterioration as a result of burial (Sim Ooi et al., 2011). Clonal integration is a mechanism to cope with chronic, small-scale, burial events such as those induced by waves on shallow sediments and/or by bioturbators (Suchanek, 1983; Duarte et al., 1997). It remains untested, however, the specific physiological mechanisms that may promote seagrass survivorship when the clonal integration is preserved. Most likely, nutrients and a range of resources are transferred from undisturbed to disturbed shoots, as a way to face unfavourable conditions during periods of elevated stress (Tomasko and Dawes, 1989). Actively growing meristems might also organize the sharing of resources within the clone (Terrados et al., 1997a,b; Marbá et al., 2002) and facilitate 
the survivorship of some shoots at the expense of others. Clonal integration facilitates the growth of seagrass shoots in shaded microhabitats (Tomasko and Dawes, 1989) and the coexistence between freshwater macrophytes competing for resources (Xiao et al., 2011). However, shoots placed in microhabitats where resources are limited might not be supported when connected to actively growing shoots placed in microhabitats with higher resource availability (Wolfer and Straile, 2012).

An increase in the vertical growth of seagrasses is one of the conspicuous responses of seagrasses to burial events (Duarte et al., 1997; Cabaço et al., 2008). In our study, the capacity of $C$. nodosa to respond to burial was demonstrated by the enhanced internodal length of vertical rhizomes. Moderate levels of burial typically stimulate the vertical growth of surviving seagrass shoots: this response has been detected for a suite of seagrasses, including Cymodocea nodosa seedlings (Marbá and Duarte, 1994), and other seagrasses, e.g. Cymodocea serrulata (Sim Ooi et al., 2011), Posidonia oceanica (Manzanera et al., 2011) and Zostera noltii (Cabaço and Santos, 2007). This reaction relocates the shoot meristem closer to the substrate surface, and so a decrease in the amount of photosynthetic tissue that remains buried (Terrados, 1997).

In the Mediterranean, seedlings of $C$. nodosa have shown a certain capacity to respond to small-scale burial events in mesocosms (Marbá and Duarte, 1994). Comparisons in the vulnerability of seagrass performance between this study and our results should be taken with caution, since seedlings are less resilient that mature shoots to disturbances such as burial. Therefore, comparisons of thresholds of $C$. nodosa tolerance to burial are not possible between the Mediterranean and Gran Canaria. In any case, there is a certain degree of convergence between both studies. For example, the shoot density and the leaf length decreased in all cases under severe burial treatments. 
Seagrass responses to burial can be affected by the timing of events, i.e. seasonality (Manzanera et al., 2011). Our experiment was performed during spring-summer; this is the period of maximum seagrass growth of C. nodosa in the Canaries (Reyes et al., 1995; Tuya et al., 2006). As a result, C. nodosa could have been more severely affected by increasing burial levels if the experimental setup would have been established during winter. Moreover, our results are limited to one meadow and a duration of 15 weeks. In this sense, distinct meadows can differ in a range of environmental variables, e.g. nutrients concentrations in the substrate, porewater $\mathrm{pH}$ and sulphides, etc, that can affect seagrass responses to burial. Burial effects may be detrimental if the size of the area affected by burial, or the distance to undisturbed shoots, are larger than distances at which clonal integration is maintained (Terrados et al., 1997a,b; Marbá et al., 2002). As a result, the negative effects of burial on $C$. nodosa performance should not be underestimated, particularly since burial episodes associated with major storms or coastal works can bury large areas $\left(10 \mathrm{~s}\right.$ to $100 \mathrm{~s}$ of $\left.\mathrm{m}^{2}\right)$ covered by this seagrass, and so reduce the presence of undisturbed shoots that can promote recovery of adjacent shoots through preservation of the clonal integration.

Acknowledgements. This study was funded by the Spanish Science and Innovation Ministerial Authority “Plan Nacional”, reference CGL2010-18545. FT was supported by the 'Ramón y Cajal' program from the Spanish Government. We acknowledge Tony Sánchez and Harue Hernández for their help during fieldwork. Two anonymous reviewers provided positive feedback on a previous draft.

\section{References}

Anderson, M.J., 2001. A new method for non-parametric multivariate analysis of variance. Aust. Ecol. 26, 32-46. 
Barberá, C., Tuya, F., Boyra, A., Sánchez-Jerez, P., Blanch, I., Haroun, R.J., 2006. Spatial variation in the structural parameters of Cymodocea nodosa seagrass meadows in the Canary Islands: a multiscaled approach. Bot. Mar. 48, 122-126.

Cabaço, S., Santos, R., 2007. Effects of burial and erosion on the seagrass Zostera noltii. J. Exp. Mar. Biol. Ecol. 340, 204-212.

Cabaço, S., Santos, R., Duarte, C.M., 2008. The impact of sediment burial and erosion on seagrasses: a review. Estuar. Coast. Shelf Sci. 79, 354-366.

Duarte, C.M., Terrados, J., Agawin, N.S.R., Fortes, M.D., Bach, S., Kenworthy, J., 1997. Response of a mixed Philippine seagrass meadow to experimental burial. Mar. Ecol. Prog. Ser. 147, 285-294.

Espino, F., Tuya, F., Brito, A., Haroun, R.J., 2011. Ichthyofauna associated with Cymodocea nodosa meadows in the Canarian Archipelago (central eastern Atlantic): community structure and nursery role. Cienc. Mar. 37, 157-174.

Hemminga, M.A., Duarte, C.M., 2000. Seagrass Ecology. Cambridge Univ. Press, London.

Holmer, M., Duarte, C.M., Marbá, N., 2005. Iron additions reduce sulfate reduction rates and improve seagrass growth on organic enriched carbonate sediment. Ecosystems $8,721-730$. 
Holmer, M., Marbá, N., Lamote, M., Duarte, C.M., 2009. Deterioration of sediment quality in seagrass meadows (Posidonia oceanica) invaded by macroalgae (Caulerpa sp.). Estuar. Coast. 32, 456-466.

Hughes, A.R., Williams, S.L., Duarte, C.M., Heck, K.L., Waycott, M., 2009. Associations of concern: Declining seagrasses and threatened dependent species. Front. Ecol. Environ. 7, 242-246.

Manzanera, M., Alcoverro, T., Tomas, F., Romero, J., 2011. Response of Posidonia oceanica to burial dynamics. Mar. Ecol. Prog. Ser. 423, 47-56.

Marbá, N., Duarte, C.M., 1994. Growth response of the seagrass Cymodocea nodosa to experimental burial and erosion. Mar. Ecol. Prog. Ser. 107, 307-311.

Marbá, N., Cebrián, J., Enríquez, S., Duarte, C.M., 1994. Migration of large-scale subaqueous bedforms measured with seagrass (Cymodocea nodosa) as tracers. Limnol. Oceanogr. 39, 126-133.

Marbá, N., Hemminga, M.A., Mateo, M.A., Duarte, C.M., Mass, Y.E.M., Terrados, J., Gacia, E., 2002. Carbon and nitrogen translocation between seagrass ramets. Mar. Ecol. Prog. Ser. 226, 287-300.

Mills, K.E., Fonseca, M.S., 2003. Mortality and productivity of eelgrass Zostera marina under conditions of experimental burial with two sediment types. Mar. Ecol. Prog. Ser. $255,127-134$. 
Portillo, E., 2007. Southern swells associated with massive seagrass (Cymodocea nodosa) losses in Gran Canaria. I International Symposium on Marine Sciences/GLOBEC-IMBER, Valencia, Spain.

Reyes, J., Sansón, M., Afonso-Carrillo, J., 1995. Leaf phenology, growth and production of the seagrass Cymodocea nodosa at El Médano (south of Tenerife, Canary Islands). Bot. Mar. 38, 457-465.

Ruiz, J.M., Romero, J., 2003. Effects of disturbances caused by coastal constructions on spatial structure, growth dynamics and photosynthesis of the seagrass Posidonia oceanica. Mar. Poll. Bull. 46, 1523-1533.

Sim Ooi, J.L., Kendrick, G.A., Van Niel, K.P., 2011. Effects of sediment burial on tropical ruderal seagrasses are moderated by clonal integration. Cont. Shelf- Res. 31, $1945-1954$.

Suchanek, T.H., 1983. Control of seagrass communities and sediment distribution by Callianassa (Crustacea, Thalassinidea) bioturbation. J. Mar. Res. 41, 281-298.

Terrados, J., 1997. Is light involved in the vertical growth response of seagrasses when buried by sand? Mar. Ecol. Prog. Ser. 152: 295-299.

Terrados, J., Duarte, C.M., Kenworthy, W.J., 1997a. Experimental evidence for apical dominance in the seagrass Cymodocea nodosa. Mar. Ecol. Prog. Ser. 148, 263-268. 
Terrados, J., Duarte, C.M., Kenworthy, W.J., 1997b. Is the apical growth of Cymodocea nodosa dependent on clonal integration? Mar. Ecol. Prog. Ser. 158: 103-110.

Terrados, J., Duarte, C.M., Fortes, M.S., Borum, J., Agawin, N.S., Bach, S., Thampanya, U., Kamp-Nielson, L., Kenworthy, W.J., Geertz-Hansen, O., Vermaat, J., 1998. Changes in community structure and biomass of seagrass communities along gradients of siltation in SE Asia. Estuar. Coast. Shelf Sci. 46, 757-768.

Tomasko, D.A., Dawes, C.J., 1989. Evidence for physiological integration between shaded and unshaded short shoots of Thalassia testudinum. Mar. Ecol. Prog. Ser. 54, 299-305

Tuya, F., Pérez, J., Medina, L., Luque, A., 2001. Variaciones estacionales de la macrofauna invertebrada de tres praderas marina de Cymodocea nodosa en Gran Canaria (Centro-Este del océano Atlántico). Cien. Mar. 27, 223-234.

Tuya, F., Martín, J.A., Luque, A., 2006. Seasonal cycle of a Cymodocea nodosa seagrass meadow and of the associated ichthyofauna at Playa Dorada (Lanzarote, Canary Islands, eastern Atlantic). Cien. Mar. 32, 695-704.

Underwood, A.J., 1997. Experiments in Ecology: their logical design and interpretation using Analysis of Variance. Cambridge University Press, London. 
Waycott, M., Duarte, C., Carruthers, T.J.B., Orth, R.J., Dennison, W.C., Olyarnik, S., Calladine, A., Fourqurean, J.W., Heck, Jr, K.L., Hughes, A.R., Kendrick, G.A., Kenworthy, W.J., Short, F.T., Williams, S.L., 2009. Accelerating loss of seagrasses across the globe threatens coastal ecosystems. Proc. Natl. Acad. Sci. USA 106, 123771238.

Wolfer, S.R., Straile, D., 2012. To share or not to share: clonal integration in a submerged macrophyte in response to light stress. Hydrobiologia 684, 261-269.

Xiao, K., Yu, D., Wang, L., Han, Y., 2011. Physiological integration helps a clonal macrophyte spread into competitive environments and coexist with other species Aquat. Bot. 95, 249-253. 


\begin{tabular}{ccccc}
\hline (a) Between subjects & DF & MS & F & P \\
\cline { 2 - 5 } Sedimentation & 2 & 987 & 69.1 & $<0.0001$ \\
Clonal Integration & 1 & 3685 & 258 & $<0.0001$ \\
Sed x CI & 2 & 125 & 8.8 & 0.002 \\
Residual & 18 & 14.3 & & \\
\hline (b) Within subjects & & & & \\
Times & 2 & 6086 & 425.2 & $<0.0001$ \\
Times x Sed & 4 & 154 & 10.8 & $<0.0001$ \\
Times x CI & 2 & 615 & 43 & $<0.0001$ \\
Times x Sed x CI & 4 & 23 & 1.6 & 0.1897 \\
Residual & 36 & 14.3 & & \\
\hline
\end{tabular}

Table 1. RM-ANOVA testing the effects of 'Sedimentation' (Sed) and 'Clonal Integration' (CI) on C. nodosa shoot survivorship through 3 consecutive 5-weeks periods (Times). 


\begin{tabular}{|c|c|c|c|c|c|c|c|c|c|c|c|c|c|c|c|c|c|c|c|}
\hline & \multicolumn{4}{|c|}{ Shoot density } & \multicolumn{3}{|c|}{ Number of leaves } & \multicolumn{3}{|c|}{ Leaf length } & \multicolumn{3}{|c|}{ Above-ground biomass } & \multicolumn{3}{|c|}{ Below-ground biomass } & \multicolumn{3}{|c|}{ Internodal length } \\
\hline & DF & MS & $\mathrm{F}$ & $\mathrm{P}$ & MS & $\mathrm{F}$ & $\mathrm{P}$ & MS & $\mathrm{F}$ & $\mathrm{P}$ & MS & $\mathrm{F}$ & $\mathrm{P}$ & MS & $\mathrm{F}$ & $\mathrm{P}$ & MS & $\mathrm{F}$ & $\mathrm{P}$ \\
\hline Sedimentation & 2 & 0.3291 & 4.3 & 0.0298 & 0.0864 & 0.97 & 0.3981 & 108.5463 & 3.07 & 0.0713 & 0.1172 & 1.91 & 0.177 & 0.2252 & 2.60 & 0.1021 & 0.068 & 10.81 & 0.0008 \\
\hline Clonal Integration & 1 & 0.0054 & 0.07 & 0.7934 & 0.0021 & 0.02 & 0.8796 & 5.6357 & 0.16 & 0.6944 & 0.0007 & 0.01 & 0.916 & 0.0063 & 0.07 & 0.7899 & 0.027 & 4.28 & 0.0532 \\
\hline Sed x CI & 2 & 0.419 & 5.46 & 0.0091 & 0.6233 & 6.99 & 0.0057 & 255.6441 & 7.23 & 0.0050 & 0.6872 & 11.19 & 0.0004 & 0.0430 & 0.50 & 0.6170 & 0.193 & 30.72 & 0.0001 \\
\hline Residual & 18 & 0.0766 & & & 0.0891 & & & 35.3617 & & & & & & 0.0867 & & & 0.006 & & \\
\hline
\end{tabular}

0 Table 2. Results of 2-way ANOVAs testing the effects of 'Sedimentation' (Sed) and 'Clonal Integration' (CI) on seagrass responses after 15

1 weeks of exposure to experimental burial.

2 
$7 \quad$ Figure captions

8

9 Figure 1. Patterns in living C. nodosa seagrass shoot decline (percentage relative to 10 initial values) through time under different burial scenarios when (A) the clonal 11 integration was maintained and (B) severed.

12

13 Figure 2. Seagrass responses after 15 weeks of exposure to experimental burial. Error 14 bars are + SE of means. Grey bars provide a baseline (control) to visually compare 15 seagrass responses. Different letters above bars denote significant differences (pairwise 16 comparisons) among burial levels when the clonal integration was severed (non-CAPS 17 letters) or maintained (CAPs letters). 


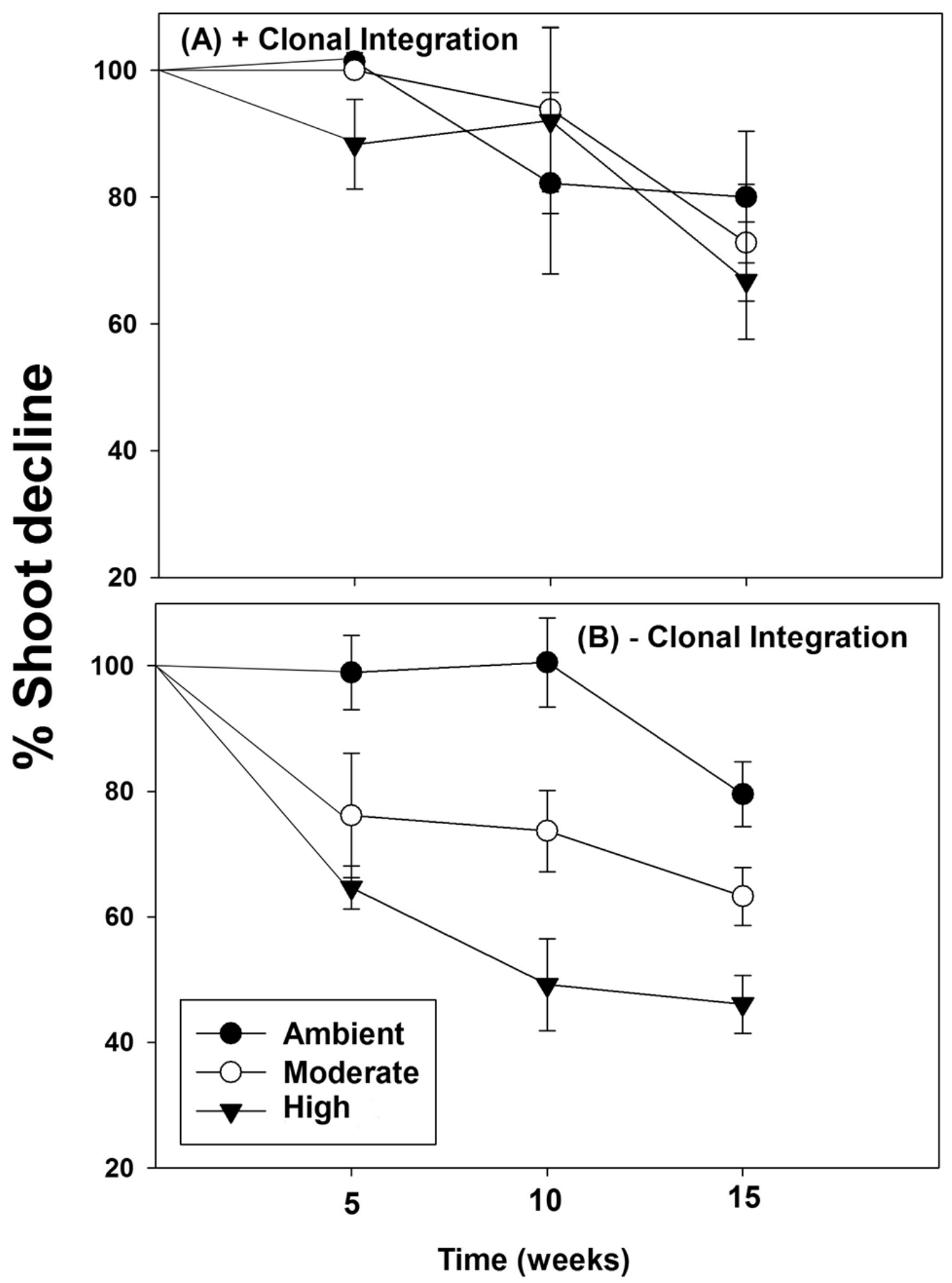

$20 \quad$ Fig. 1 

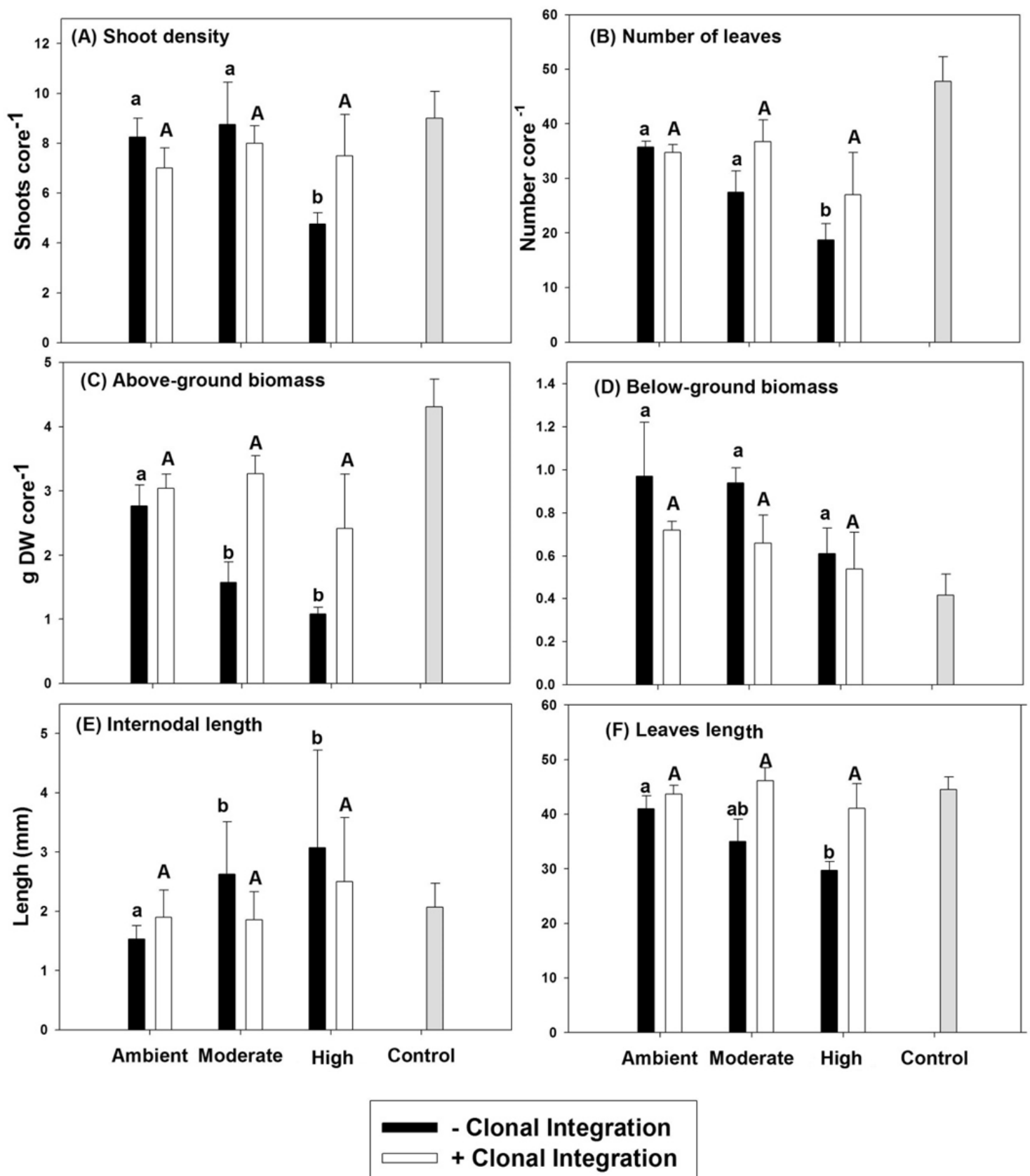

Fig. 2 